\title{
Thinking and Exploration of College Students' Comprehensive Ability Training under the Background of "Innovation and Entrepreneurship"
}

\author{
Qin Yanli ${ }^{\mathrm{a}}$, Xie Haijun \\ School of business, Qingdao Binhai University, Qingdao, Shandong, 266555, China \\ aqinyanlisd@126.com
}

Keywords: Innovation and Entrepreneurship; college students; comprehensive ability.

\begin{abstract}
Innovation and Entrepreneurship" provides a better social environment for college students, but also requires students' comprehensive ability to meet the requirements of "Innovation and Entrepreneurship". As the representative of advanced productive forces, college students should be the main force of "double innovation". Therefore, the cultivation of college students' comprehensive ability must adopt a reasonable way, closely adhere to the form of "Innovation and Entrepreneurship", and pay attention to the cultivation of students' innovation and entrepreneurial ability, in order to inject new vitality into the development of society. Based on this, this paper starts with the importance of cultivating college students' comprehensive ability under the background of "Innovation and Entrepreneurship", analyzes the content of cultivating college students' comprehensive ability under the background of "Innovation and Entrepreneurship", and then discusses the measures of cultivating college students' comprehensive ability under the background of "Innovation and Entrepreneurship", with a view to cultivating college students' comprehensive ability under the background of "Innovation and Entrepreneurship", providing some reference for training.
\end{abstract}

\section{Overview of "double innovation"}

"Double innovation" is a call put forward by Premier Li Keqiang, which aims to encourage innovation and entrepreneurship, and provide more support for social development. At present, the state has promulgated a series of policies to provide a better environment for entrepreneurship and innovation, especially in the current stage of national economic transformation, help to stimulate the creativity of the masses, and provide a better platform for the people to play.

After putting forward the policy of "the State Council's Opinions on Several Policies and Measures for Promoting the Innovation of the Mass Entrepreneurs", the number of small and micro enterprises in China has been increasing rapidly, especially the encouraging policies of the government departments, which have greatly lowered the threshold for small enterprises to enter the market and attracted a large number of entrepreneurs. . In addition, the restrictions on household registration and academic qualifications were eliminated, and an information sharing platform was created, which greatly promoted the development of innovation.

\section{The importance of cultivating comprehensive abilities of College Students under the background of "double innovation"}

The main force of innovation and entrepreneurship is college students, but in the market economy environment, although there are policies to support, still need college students with excellent comprehensive ability. Specifically, in the context of "double innovation". The importance of training college students' comprehensive ability is mainly reflected in the following points:

(1) Relieve employment pressure. With the rapid development of higher education in China, the number of college students has been greatly improved. However, the training mechanism and curriculum design of higher education in China are out of touch with the actual needs of the market, 
so the comprehensive ability of college graduates is on the low side, leading to the employment situation is not optimistic. Moreover, in recent years, the economic growth of the society has slowed down, and the demand of the society has declined, which further increases the employment pressure. In this environment, we should start with the cultivation of talents, focus on improving the comprehensive ability of College students, so that students more in line with the employment standards of enterprises, ease the pressure of employment.

(2) Adapt to the new requirements of "double innovation". College students represent the advanced productive forces of society, shoulder the mission of national development, and are the future successors of the country. At present, China's socialist market economy system has tended to be perfect, the country is undergoing strategic economic restructuring, so the community on the comprehensive quality of college students put forward higher requirements, not only requires students with a solid theoretical basis, but also with practical and innovative ability. Especially under the background of "double innovation", colleges and universities should cultivate students'ability to discover, think and solve problems, and use innovation to promote scientific and technological progress. In the fierce market competition, college students need to have more excellent comprehensive quality, improve scientific research ability, innovation ability, which is also conducive to the realization of personal value.

(3) Alleviate the pressure of College Students' family economy. About $40 \%$ of the poverty-stricken students in Colleges and universities accounted for 10\%-25\%. Poverty-stricken students group is relatively special, because of the growth environment and other reasons, they have certain problems in interpersonal communication, is the lack of motivation and opportunities for innovation and entrepreneurship. Work departments in Colleges and universities have also been focusing on the problem of poor students, which is helpful both in policy and economy, but is slightly inadequate in innovation, entrepreneurship and scientific research. Under the background of "double innovation", the threshold of innovation and Entrepreneurship of college students has been greatly reduced, so focusing on cultivating their comprehensive ability will help to improve their employment quality and improve the family economic situation of College students.

\section{Cultivating the comprehensive ability of College Students under the background of "double innovation"}

Under the background of "double innovation", higher requirements have been put forward for the comprehensive ability of College students, which requires students to have long-term development qualifications in interpersonal communication, life, psychology, work, growth and scientific research innovation besides learning ability. Under the traditional teaching mode and system, schools pay more attention to the study of theoretical knowledge, students have less time, and the cultivation of innovative ability is not in place. To some extent, the cultivation mode affects the students'independent play. Therefore, when college students graduate, they can not quickly combine theory with practice, lack of innovation in their work, and disconnect from the requirements of enterprises. Combining with the current trend of the times and the demand of "double innovation", the training contents of College Students'comprehensive ability mainly include the following points:

(1) Observation ability. Observing ability refers to the ability of college students to find problems. Only by constantly improving and perfecting the problems, can they constantly innovate. The keen observation ability can make college students discover more information, which is the process of collecting external data and lays a foundation for subsequent innovation and creation.

(2) Practical ability. Practical ability refers to the ability to apply theoretical knowledge to real life and work, which requires practice on the basis of skilled theory, and then deepen the theory in practice. In the cultivation of colleges and universities, the cultivation of practical ability can be realized through practice and other means, and can also be combined with theoretical teaching and practical experience to strengthen the cultivation of students'practical ability, so as to enhance the comprehensive ability of College students.

(3) Thinking ability. Thinking ability refers to people's concrete and abstract analysis of problems, 
while summarizing a series of processes, it is more perceptual knowledge of external information, and through their own logical thinking to judge and summarize, which is an indispensable process in people's learning activities, but also the core of innovation and creation. The cultivation of College Students' thinking ability is particularly important, it needs to use systematic learning to carry out creative, agile and profound training, in order to constantly enhance the thinking ability.

(4) Integration capability. Integration ability is the effective integration of resources, is in the practice of innovation, the use of existing forms of resources for more forms of collocation and combination, while achieving the optimal configuration, in order to achieve the purpose of $1+1$ greater than 2 .

(5) Communication skills. Communicating ability refers to communicating and expressing, conveying their thoughts to each other. Communication ability is very important for the requirement of double-innovation environment, because innovation and creation are often impossible to achieve alone, and need teamwork to achieve the ultimate goal, which requires college students to have good communication skills. At the same time, the ability to communicate is also the key to ensure physical and mental health, for the cultivation of College Students' comprehensive quality is of great significance.

\section{Training measures for cultivating comprehensive abilities of College Students under the background of "double innovation"}

\subsection{Strengthening Mental Health Education}

Psychological health education has an important impact on the long-term development of College students, so it is necessary to strengthen mental health education in the training of comprehensive ability. In the process of teaching, we must guide students correctly, let them realize their strengths and enhance their confidence in learning. At the same time, we should give students an open platform, so that students can play independently, if the students' performance is excellent, we should give positive, so that students in practice continue to find themselves, to establish the consciousness of self-improvement. Under the environment of double innovation, college students are required to possess better psychological quality and be able to innovate and start an undertaking with confidence. This highlights the importance of mental health education, because innovation and entrepreneurship often bear certain risks, but also need to sum up experience in constant failure. If the psychological quality is not up to standard, it can not stubbornly carry out innovation and entrepreneurship.

\subsection{Deepening of career planning education}

Career education can help students enhance their personal strength, and also help to explore their potential. At the same time, career education can also help students to plan their own development purposefully and planned, which is of great significance to the promotion of independent innovation and entrepreneurial success.

Career planning is not only to help students find suitable jobs, but also to enable students to maximize their personal goals according to personal circumstances, while making the right plan for their future. Therefore, when carrying out career planning education in Colleges and universities, it is necessary to let students know their own situation and determine a reasonable and feasible direction of development. Of course, the specific forms can be diversified, using mobilization meetings, class meetings and other forms to organize the training of students. When individual students have problems, they can also carry out career planning guidance separately, and carry out systematic training in different levels and stages. Only in this way can students realize the significance of career planning, and help students to establish the direction, help students better integrate into society, carry out innovative and entrepreneurial activities.

\subsection{Cultivation of innovation consciousness}

College students' innovative consciousness plays a decisive role in innovation and 
entrepreneurship. Only when students' subjective will is biased towards innovation and entrepreneurship can they put it into practice. However, from the current comprehensive ability training in Colleges and universities, the lack of innovation awareness, so more students choose ordinary employment rather than independent entrepreneurship. However, from the current economic situation in China, the speed of development is gradually slowing down, so the employment situation is more severe, college students are facing greater pressure after graduation, if the choice of independent entrepreneurship can effectively solve the employment problem, but also conform to the trend of the times. Based on this, colleges and universities must attach importance to the guidance of innovative consciousness in the cultivation of students' comprehensive quality, constantly improve the mechanism under the environment of double-innovation, at the same time reform the teaching system, use the Internet platform to create environment and opportunities for students, support outstanding student projects, so that students can accumulate experience in the process of practice. It is an innovative comprehensive talent.

The cultivation of innovative consciousness must begin with practice, so the cultivation of innovative consciousness should be carried through in the whole process of educating students. Only in this way can we cultivate high-quality talents with innovative consciousness and provide strong support for the development of society.

\subsection{System upgrading of comprehensive capabilities}

Judging from the actual situation in China, most of the current students are only children, their practical ability is poor, and lack of interpersonal skills and communication skills. Especially under the strong impact of Western ideology, most college students lack team consciousness and advocate personal heroism, so they are slightly deficient in comprehensive ability. Based on this, in the process of college students' education, we should take the promotion of comprehensive ability as the key content, use student cadres and other forms to form an effective benchmark, and guide students to participate in colorful campus life. In addition, we can also enrich students' extracurricular life through various types of competitions, sports games and so on, so that students can exercise themselves in campus practice, and constantly improve their comprehensive ability, in order to meet the needs of society. The cultivation of comprehensive ability comes from campus life more, and classroom education plays a supplementary role. Only by combining theory with practice closely, can a systematic training system be formed, which enables students to experience the role of improving comprehensive ability effectively, which has a very favorable impact on their long-term development.

\section{Conclusion}

At present, our country is in the critical stage of economic transformation, and the society needs a large number of talents to provide support for economic transformation. Therefore, in order to meet the needs of the times, colleges and universities are carrying out personnel training to convey high-quality comprehensive elite students. Especially in the environment of "double innovation", the state and government provide a better platform to encourage innovation and entrepreneurship, which provides more opportunities for the development of College students. Therefore, colleges and universities should pay attention to training students' comprehensive ability. Therefore, according to the situation of our country, this paper analyzes the measures that colleges and universities can take in cultivating students' comprehensive abilities, and probes into the concrete measures from four aspects: the strengthening of mental health education, the deepening of career planning education, the cultivation of innovative consciousness and the systematic promotion of comprehensive abilities, hoping to give college students comprehensive abilities training. There is a certain direction for improvement. 


\section{Acknowledgements}

Ministry of Education 2017 "Industry-University Cooperation and Cooperative Education" Project Title "Development and Construction of Course System Based on Dual-Creative Ability Training in Applied Universities", No. 201701063014. The general title of the 13th Five-Year Plan for Educational Science of the Chinese Association of Higher Education is "University of Applied Technology" and "Research on the Integration of Ability Cultivation and Professional Practice Teaching", No. 16YB073.

\section{References}

[1] Pan Mingming.Exploration and Reflection on the Cultivation of Foreign Language Ability of Local College Students--Taking Jiamusi University as an Example[J].Journal of Social Sciences, Jiamusi University, 2018,36(02): 185-186+196.

[2] Wang Yan, Yuan Xinhui, Sun Fuliang. Exploration and Practice of Cultivating Comprehensive Ability of Biotechnology Majors in National Universities [J].Forum on Education and Teaching, 2017 (29): 158-159.

[3] Guo Yanan, Gao Huayun. Reflections on the Cultivation of Comprehensive Design Ability of Sculpture Art Majors in Colleges and Universities [J].Grand View of Fine Arts, 2012 (04): 181.

[4] Song Jie, Yang Shuangyuan. Exploration and Reflection on the Cultivation of Students'Applied Ability in the Chinese Department of Universities: Taking the "13511" Project of the Chinese Department of Yuncheng University as an Example [J].Journal of Yuncheng University, 2012, 30 (01): 78-80.

[5] Luo Zhiyong, Zhang Shengtao, Zhou Xiaomei, Deng Yin. Exploration and Thinking on Cultivating College Students'Innovative and Practical Ability [J].Experimental Technology and Management, 2009, 26 (07): 28-30. 